Article

\title{
Distribution, Pest Status and Fungal Associates of Euwallacea nr. fornicatus in Florida Avocado Groves
}

\author{
Daniel Carrillo ${ }^{1, *}$, Luisa F. Cruz ${ }^{1}$, Paul E. Kendra ${ }^{2}$, Teresa I. Narvaez ${ }^{1}$, Wayne S. Montgomery ${ }^{2}$, \\ Armando Monterroso ${ }^{3}$, Charlotte De Grave ${ }^{1,4}$ and Miriam F. Cooperband ${ }^{5}$ \\ 1 IFAS-Tropical Research and Education Center, University of Florida, Homestead, FL 33031, USA; \\ luisafcruz@ufl.edu (L.F.C.); tnarvaez1@ufl.edu (T.I.N.); charlottedegrave@ufl.edu (C.D.G.) \\ 2 Subtropical Horticulture Research Station, Agricultural Research Service, United States Department of \\ Agriculture, Miami, FL 33158, USA; Paul.Kendra@ars.usda.gov (P.E.K.); \\ wayne.montgomery@ars.usda.gov (W.S.M.) \\ 3 Brooks Tropicals, LLC, Homestead, FL 33090, USA; Armando@brookstropicals.com \\ 4 Gembloux Agro-Bio Tech, University of Liège, Gembloux B-5030, Belgium \\ 5 Otis Laboratory, Plant Protection and Quarantine's Science and Technology, Animal and Plant Health \\ Inspection Service, United States Department of Agriculture, Buzzards Bay, MA 02542, USA; \\ miriam.f.cooperband@aphis.usda.gov \\ * Correspondence: dancar@ufl.edu; Tel.: +1-786-217-9245
}

Academic Editor: Brian T. Forschler

Received: 2 August 2016; Accepted: 5 October 2016; Published: 14 October 2016

\begin{abstract}
Members of a complex of cryptic species, that correspond morphologically to the ambrosia beetle Euwallacea fornicatus (Eichhoff) (Coleoptera: Curculionidae: Scolytinae), were recently found attacking avocado (Persea americana Mill.) in Israel and California. In early 2016, an outbreak of another member of this species complex was detected infesting approximately 1500 avocado trees in an avocado orchard at Homestead, Florida. An area-wide survey was conducted in commercial avocado groves of Miami-Dade County, Florida to determine the distribution and abundance of E. nr. fornicatus, to identify different populations of E. nr. fornicatus and their fungal associates, and to assess the extent of damage to avocado trees. Ewallacea nr. fornicatus were captured in 31 of the 33 sampled sites. A sample of 35 beetles from six different locations was identified as E. nr. fornicatus sp. \#2, which is genetically distinct from the species causing damage in California and Israel. Eleven fungal associates were identified: an unknown Fusarium sp., AF-8, AF-6, Graphium euwallaceae, Acremonium sp. Acremonium morum, Acremonium masseei, Elaphocordyceps sp. and three yeast species. The unknown Fusarium isolates were the most abundant and frequently found fungus species associated with adult beetles and lesions surrounding the beetle galleries. In addition to fungal associates, three bacteria species were found associated with adult $E$. nr. fornicatus. Visual inspections detected significant damage in only two orchards. A large number of beetles were captured in locations with no apparent damage on the avocado trees suggesting that $E$. nr. fornicatus are associated with other host(s) outside the groves or with dead trees or branches inside the groves. More research is needed to determine the potential threat $E$. nr. fornicatus and its fungal associates pose to the avocado industry and agricultural and natural ecosystems in Florida.
\end{abstract}

Keywords: ambrosia beetles; symbiosis; Fusarium

\section{Introduction}

Ambrosia beetles (Coleoptera: Curculionidae: Scolytinae) have recently emerged as important pests of avocado (Persea americana Mill.; Laurales: Lauraceae), because they have been found to vector plant pathogens to this food crop. Florida's US $\$ 100$ million avocado industry is being threatened by laurel wilt (LW), a lethal disease of members of the Lauraceae that is caused by Raffaelea lauricola 
T.C. Harr. Fraedrich \& Aghayeva (Ophiostomatales: Ophiostomataceae). This disease is vectored by Xyleborus glabratus Eichhoff (Coleoptera: Curculionidae) and likely X. volvulus (F.) and X. ferrugineus (F.), which are more prevalent in the avocado production region of south Florida [1].

In addition, members of a complex of cryptic species that correspond morphologically to the ambrosia beetle, Euwallacea fornicatus (Eichhoff) (Coleoptera: Curculionidae: Scolytinae), the tea shot hole borer, have been found attacking avocado (P. americana) in Israel, California, and more recently, in Florida. A phylogenetic analysis of beetles and fungi collected from different parts of the world revealed the existence of a complex of cryptic species of E. fornicatus and Ambrosia Fusarium (AF), which is composed of at least five beetle species and nine fungal species that are all genetically distinct [2]. Two species, the polyphagous shot hole borer (PSHB) or E. nr. fornicatus sp. \#1 per O'Donnell et al. 2015 [2], and E. nr. fornicatus sp. \#5, have been reported to attack more than 300 host species in 58 plant families; including avocado in California [3]. Euwallacea nr. fornicatus sp. \#1 also has been found attacking avocado in Israel [4]. Euwallacea nr. fornicatus sp. \#1 forms symbiotic associations with Fusarium euwallaceae, Graphium euwallaceae, Paracremonium pembeum, and E. nr. fornicatus sp. \#5 does so with Fusarium sp. AF-12 and Graphium sp. [2,3,5,6].

Populations of E. nr. fornicatus were first detected in a commercial avocado orchard in south Florida in 2012 [7]. Specimens collected from the location of the original detection were determined to be genetically distinct from California's PSHB and E. nr. fornicatus sp. \#5 [2,3] and subsequently referred to as E. nr. fornicatus sp. \#2 [2]. Kasson et al. [8] identified two ambrosia fusaria (AF-6 and AF-8) cultivated by E. nr. fornicatus sp. \#2. In addition, Cooperband et al. [9] observed that a single foundress produced her first adult female offspring within 22 days of gallery initiation at $24{ }^{\circ} \mathrm{C}$, and averaged 24.7 adult female offspring within 6-7 weeks, and that the average sex ratio (\% male) was $7.2 \%$.

Subsequent surveys in south Florida from 2013 to 2015 revealed the presence of E. nr. fornicatus beetles in one mango and seven additional avocado orchards [10,11]. In all of these cases the E. nr. fornicatus populations were considered sparse and did not cause conspicuous damage to avocado or other crops. In early 2016, an outbreak of E. nr. fornicatus was detected in a 20-acre (8.1 ha) avocado orchard at Homestead, Florida, infesting approximately 1500 avocado trees in the grove [12]. The observed damage resembled that caused to avocado by PSHB in California. The beetles initially attacked junctions of small and mid-size shaded branches in the upper canopy, inoculating their fungal associates and causing localized lesions characterized by discoloration of the xylem tissue. The initial attack induced a conspicuous response by the plant, which produced white exudates referred to as "sugar volcanoes" [3]. The infestation progressed causing branch dieback, and copious breeding of the beetles occurred in decaying branches. Thereafter, attacks to larger limbs and the main trunk were observed. The similarity between the damage caused to avocado in Florida and California and the limited number of specimens used for initial characterization of the Florida species raised the question of whether other species of the E. nr. fornicatus complex were present in Florida. To address this question, an area-wide survey was conducted in the avocado production region of Miami-Dade County, Florida, which is located at the tip of the peninsula.

The objectives of this study were to determine the distribution and abundance of E. nr. fornicatus in south Florida's commercial avocado groves, to identify different populations of E. nr. fornicatus and their fungal associates, and to assess the extent of damage caused to avocado trees.

\section{Materials and Methods}

\subsection{Area-Wide Survey for E. nr. fornicatus Beetles in the Avocado Production Region of Miami-Dade County, Florida}

The Florida avocado industry consists of approximately 7000 acres [13] located in the southernmost part of Miami-Dade County to the east of Everglades National Park and west of Biscayne Bay (Figure 1). Over 98 percent of the avocados grown commercially in Florida are grown in this area. Orchard size ranges from 0.1 to over 500 acres (0.04-202 ha), with 86 percent of the farms less than 
15 acres (6 ha) [14]. Thirty-three avocado orchards distributed throughout the avocado growing region were selected as sites for the survey (Figure 1). The orchard in which an outbreak of E. nr. fornicatus was detected in January 2016 was included in the survey.

Two traps were deployed at each site. Traps consisted of two white sticky panels $(23 \times 28 \mathrm{~cm}$, Sentry wing trap bottoms; Great Lakes IPM, Vestaburg, MI, USA) baited with lures containing quercivorol (ChemTica USA, Durant, OK, USA) and 50\% $\alpha$-copaene (Synergy Semiochemical Corp., Burnaby, BC, Canada) - the two best attractants currently known for E. nr. fornicatus [10,15]. Using wire hooks, traps were hung from avocado trees at approximately $1.5 \mathrm{~m}$ of height above the ground. The two traps in each site were separated by at least $25 \mathrm{~m}$. The survey was initiated on 15 March 2016; two weeks later all traps were collected and transported to the Tropical Fruit Entomology Laboratory in Homestead, Florida for morphological identification of E. nr. fornicatus.

The abundance of E. nr. fornicatus in the orchard with a known outbreak was used as a reference to select five additional orchards with large beetle trapping numbers for molecular characterization of $E$. nr. fornicatus populations and their associated fungi. The six selected orchards were located in the center $(N=2)$ and along the edges $(N=4)$ of the avocado growing area at Homestead, Florida (Figure 1). At each of these orchards, visual inspections were conducted to assess the damage caused by E. nr. fornicatus beetles, and infested branches were collected from five trees. Five additional branches were collected from the orchard with the known outbreak. From each of the branches collected at each site, one female beetle and a sample of xylem tissue associated with the beetle gallery were removed for identification of the beetle species and fungal associates.

Beetles collected from excavated galleries were surface-disinfected with 95\% ethanol for $1 \mathrm{~min}$ and subsequently washed with distilled sterile water three times. Heads were removed and heads and bodies were individually macerated in $100 \mu \mathrm{L}$ of water. Total genomic DNA was extracted from beetle bodies using a modified cetyl trimethyl-ammonium bromide (CTAB) protocol [16]. Portions of the cytochrome oxidase subunit, elongation factor- $1 \alpha, \mathrm{CAD}$ protein, arginine kinase and mitochondrial 16S rDNA were amplified using oligonucleotide primers LCO1490 and HCO2198, ets149 and efa754, apCADforB2 and apCADrevlmod, forB2 and rev B2, LR-J-12961 and LR-N-13398 [17,18]. Nucleotide BLAST (Basic Local Alignment Search Tool) alignments were carried out for beetle identification.

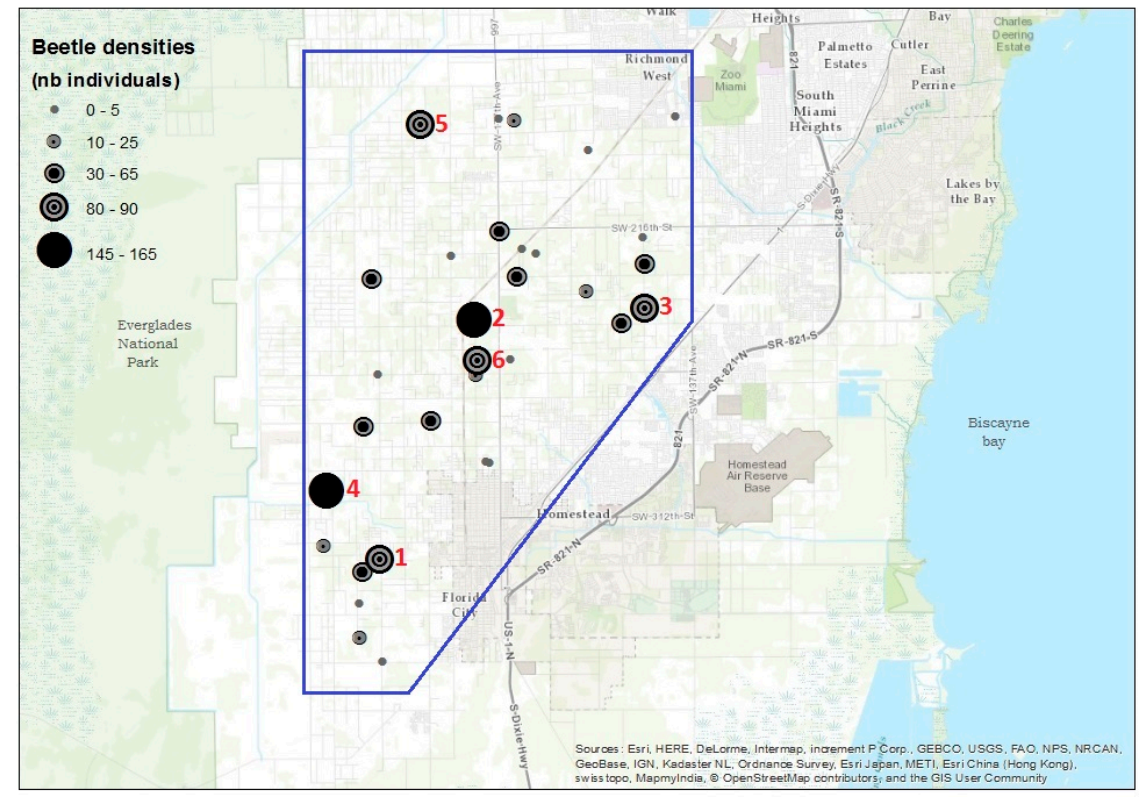

Figure 1. Distribution and abundance of Euwallacea nr. fornicatus in the avocado growing region in south Florida (enclosed in the blue polygon). Circles of different sizes represent the total number of E. nr. fornicatus beetles captured per avocado orchard. 


\subsection{Fungal Isolations from Plant Tissue and Beetles}

Sections of discolored sapwood obtained from five branches per location were excised from the lesions surrounding beetle galleries and surface disinfected with ethanol and bleach. Pieces obtained from individual logs were independently plated onto potato dextrose agar supplemented with $0.1 \mathrm{~g} / \mathrm{L}$ streptomycin $\left(\mathrm{PDA}^{+}\right)$, and incubated at room temperature until the fungal growth was evident. For isolation of the beetle fungal communities, $40 \mu \mathrm{L}$ of the beetle-head macerates and $100 \mu \mathrm{L}$ of a 1:100 dilution were plated on $\mathrm{PDA}^{+}$and malt extract agar amended with $0.6 \mathrm{~g} / \mathrm{L}$ cycloheximide and $0.3 \mathrm{~g} / \mathrm{L}$ streptomycin (CSMA). Colonies of representative morphotypes were counted and transferred onto new plates to obtain pure cultures.

DNA was extracted from the mycelium of pure cultures obtained for single-spore colonies for both plant and beetle isolates following a modified CTAB protocol [16]. The fungal isolates displaying Fusarium-like morphology were typed by sequencing portions of EF- $1 \alpha$ amplified using primers EF1 and EF2 [19] and DNA-directed RNA polymerase II largest subunit RBP1 using primers F5/R8 and F8/R9 [2], and second largest subunit RBP2, 5f2/7cr and 7cf/11ar [20]. A portion of the nuclear large subunit (LSU) 28S ribosomal DNA was amplified for the identification of other fungal isolates using primers LR0R/LR5 [21]. Graphium spp. isolates identified by the above LSU primers were additionally typed using portions of the small subunit rDNA with primers NS1/NS4 [22]. Bacterial isolates were identified by amplifying and sequencing $16 \mathrm{~S}$ rRNA using the primer set 63F/1387R [23]. PCR products were purified using ExoSAP-IT following the manufacturer's protocols (Affimetrix) and sequenced in both directions. PCR conditions were as reported in [2,20] for Fusarium isolates, in [21,22] for other fungal isolates and in [23] for bacteria isolates. Sequencing was performed by Eurofins MWG Operon (Louisville, KY, USA). The NCBI BLAST was used to identify the nucleotide sequences.

\section{Results}

\subsection{Area-Wide Survey for E. nr. fornicatus Beetles in the Avocado Production Region of Miami-Dade County, Florida}

During the two-week survey, a total of 1164 E. nr. fornicatus individuals were captured in 31 of the 33 sampled sites (Figure 1). Trap captures ranged from 0 to 161 female beetles with an average of $35 \pm 3.49$ (mean \pm standard error) beetles per avocado orchard. Damage and branch dieback were detected in only two of the 33 orchards including the orchard where an outbreak of E. nr. fornicatus had been detected previously.

All E. nr. fornicatus beetles collected from the six orchards with largest numbers of captures were identified as E. nr. fornicatus sp. \#2 based on 99\% identity of their five amplified gene segments COI, CAD, ArgK, 16SrRNA and EF-1 $\alpha$ with the GeneBank accession numbers KM406731.1, KM406713.1, KM406700.1, KM406749.1, and KM406749.1.

\subsection{Fungal Isolations from Plant Tissue and Beetles}

Symbiotic fungi were found in all but four of the 35 beetles sampled and eleven fungal associates were identified including three yeast species. The unknown Fusarium sp. EF-1 $\alpha$ sequence showed $99 \%$ identity match with Fusarium ambrosium GeneBank accession numbers KC691528. Similarly, sequences generated by the RBP2 primer set 7cf /11 showed 99\% match with the F. ambrosium accession number KM406645. However, the sequence generated by the RBP2 primer set 5f2/7cr displayed 99\% of identity with AF4 and no amplification was obtained for the RBP1 primer sets. The unknown Fusarium sp. was the most abundant and frequently found fungi in 28 of 35 beetles from all sampled sites. The number of Fusarium sp. colony forming units (CFU) per beetle ranged from 62-375 (Table 1, Figure 2). Graphium euwallaceae-identity based on $99 \%$ match of its 18s rRNA with the GeneBank accession number KF542895.1 — was the second most frequent and abundant fungal associate isolated from 22 of the 35 sampled beetles from all locations, with a range of 20 to 82 CFUs/per beetle. Acremonium sp.-identity based on $99 \%$ match of its LSU sequence with the accession number 
KP030843.1-was recovered from three beetles in two locations with CFUs in the ranging from 10 to 130. One beetle from location 5 was carrying five CFUs of Acremonium morum, identified by its LSU with 99\% identity with GeneBank accession FJ176880. In addition, one beetle was found carrying Acrimonium masseei that was identified by $99 \%$ identity of its LSU sequence with GeneBank accession number HQ232060. AF-8 - of which EF-1 $\alpha$ and RBP2 sequences showed 99\% identity with GeneBank accession numbers KC691549.1 and KC691638.1-was isolated from two beetles carrying 60 to 95 CFUs each. AF-6 with EF-1 $\alpha$ sequence showing 100\% identity with the accession number KC691545 and RPB2 sequence with 99\% of identity with the accession number KC691634 was only found in one branch sample at location 6 (Table 1). In addition, Elaphocordyceps sp.-identified based on its LSU 99\% identity with gene bank accession number KM242367-was found associated with two E. nr. fornicatus beetles from two different locations carrying five CFUs each. The unknown Fusarium sp. was found as a single fungal symbiont in six out of 35 sampled beetles. Graphium euwallaceae was always found co-occurring with either Fusarium sp. (21 of 22 beetles) or with AF-8 (1 of 22 beetles). Acremonium species were always associated with beetles carrying Fusarium sp. and G. euwallaceae. AF-8 was found alone or together with G. euwallaceae. The yeast species identified based on their LSU sequences were: (1) Zygozyma oligophage-97\% identity with GB accession number DQ518998-present in location 6 (3 of 10 beetles, 15 CFU/beetle), (2) Hannaella sp.—99\% identity with GB accession number DQ518998KM206722-present at location 5 (1 of 5 beetles, 15 CFU/beetle), and (3) Candida germanica-98\% identity with GB accession number DQ518998AF245401-present at location 4 ( 3 of 5 beetles, $28 \mathrm{CFU} /$ beetle).

In addition to fungal associates, three bacteria species were found associated with adult E. nr. fornicatus. Bacterial isolates identified based on 16rRNA sequence include: (1) Sphingomonas sp.—99\% identity with GB accession numbers DQ202286, HM241215 and KT984987-present at locations 4 (2 of 5 beetles, 45 CFU/beetle) and 6 (4 of 10 beetles 150 CFU/beetle); (2) Ochrobactrum sp.- $99 \%$ identity with GB accession number KU902423-present at location 6 (2 of 10 beetles, 50 CFU/beetle), and (3) Chryseobacterium sp.—98\% identity with GB accession numbers KR1896216 and KM229318 - present at locations 5 ( 2 of 5, 20 CFU / beetle) and location 6 ( 1 of 10 beetles, 15 CFU / beetle).

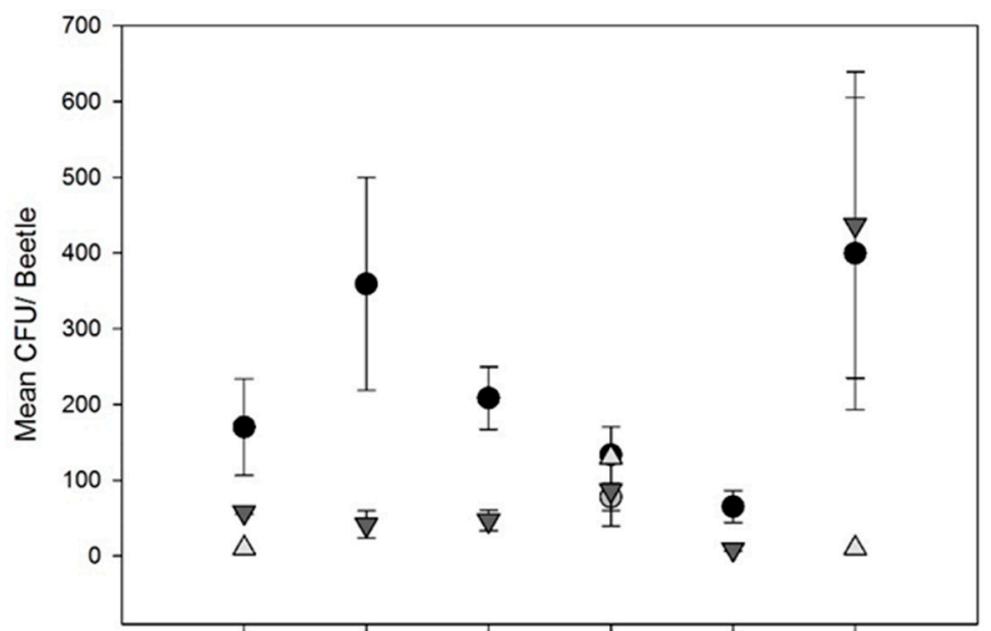

Location 1 Location2 Location 3 Location 4 Location 5 Location 6

- Fusarium sp.

Fusarium sp. AF-8

$\nabla$ Graphium euwallaceae

$\triangle$ Acremonium spp

Figure 2. Estimated abundance (CFU) of fungal species recovered from 35 E. nr fornicatus at six locations within the south Florida avocado growing region. 
Table 1. Frequency of fungal isolates recovered from 35 beetle heads and the symptomatic tree tissue of 30 logs collected in six locations in the Florida avocado growing region.

\begin{tabular}{|c|c|c|c|c|c|c|c|c|c|c|c|c|c|}
\hline \multirow{2}{*}{$\begin{array}{l}\text { Location } \\
\text { Coordinates }\end{array}$} & \multirow{2}{*}{$\begin{array}{c}\text { Isolation } \\
\text { Source }\end{array}$} & \multirow{2}{*}{ Isolate ID } & \multicolumn{10}{|c|}{ Sample } & \multirow{2}{*}{$\begin{array}{c}\text { Frequency } \\
\mathbf{n} / \mathbf{N}\end{array}$} \\
\hline & & & 1 & 2 & 3 & 4 & 5 & 6 & 7 & 8 & 9 & 10 & \\
\hline \multirow{3}{*}{$\begin{array}{c}\text { Location } 1 \\
25^{\circ} 27^{\prime} 53^{\prime \prime} \mathrm{N} \\
80^{\circ} 31^{\prime} 6^{\prime \prime} \mathrm{W}\end{array}$} & $\begin{array}{l}\text { Plant } \\
\text { tissue }\end{array}$ & Fusarium sp. & $\mathrm{x}$ & $\mathrm{x}$ & $\mathrm{x}$ & $\mathrm{x}$ & $\mathrm{x}$ & & & & & & $5 / 5$ \\
\hline & \multirow{2}{*}{ Beetle } & \multirow{2}{*}{$\begin{array}{l}\text { Fusarium sp. } \\
\text { G. euwallaceae }\end{array}$} & \multirow[t]{2}{*}{$\mathrm{x}$} & & \multirow[t]{2}{*}{$\mathrm{x}$} & $\mathrm{x}$ & $\mathrm{x}$ & & & & & & $4 / 5$ \\
\hline & & & & & & $\mathrm{x}$ & $\mathrm{x}$ & & & & & & $2 / 5$ \\
\hline \multirow{3}{*}{$\begin{array}{c}\text { Location } 2 \\
25^{\circ} 32^{\prime} 16^{\prime \prime} \mathrm{N} \\
80^{\circ} 29^{\prime} 11^{\prime \prime} \mathrm{W}\end{array}$} & $\begin{array}{l}\text { Plant } \\
\text { tissue }\end{array}$ & Fusarium sp. & $\mathrm{x}$ & $\mathrm{x}$ & $\mathrm{x}$ & $\mathrm{x}$ & $\mathrm{x}$ & & & & & & \\
\hline & \multirow{2}{*}{ Beetle } & Fusarium sp. & $\mathrm{x}$ & $\mathrm{x}$ & $\mathrm{x}$ & $\mathrm{x}$ & $\mathrm{x}$ & & & & & & $5 / 5$ \\
\hline & & G. euwallaceae & $\mathrm{x}$ & $\mathrm{x}$ & $\mathrm{x}$ & $\mathrm{x}$ & & & & & & & $4 / 5$ \\
\hline \multirow{4}{*}{$\begin{array}{c}\text { Location } 3 \\
25^{\circ} 32^{\prime} 28^{\prime \prime} \mathrm{N} \\
80^{\circ} 25^{\prime} 44^{\prime \prime} \mathrm{W}\end{array}$} & $\begin{array}{l}\text { Plant } \\
\text { tissue }\end{array}$ & Fusarium sp. & $\mathrm{x}$ & $\mathrm{x}$ & $\mathrm{x}$ & $\mathrm{x}$ & $\mathrm{x}$ & & & & & & \\
\hline & \multirow{3}{*}{ Beetle } & Fusarium sp. & & & $\mathrm{x}$ & $\mathrm{x}$ & $\mathrm{x}$ & & & & & & $3 / 5$ \\
\hline & & G. euwallaceae & & & $\mathrm{x}$ & $\mathrm{x}$ & $\mathrm{x}$ & & & & & & $3 / 5$ \\
\hline & & A. masseei & & & & & $\mathrm{x}$ & & & & & & $1 / 5$ \\
\hline \multirow{6}{*}{$\begin{array}{c}\text { Location } 4 \\
25^{\circ} 29^{\prime} 8^{\prime \prime} \mathrm{N} \\
80^{\circ} 32^{\prime} 11^{\prime \prime} \mathrm{W}\end{array}$} & $\begin{array}{l}\text { Plant } \\
\text { tissue }\end{array}$ & Fusarium sp. & $\mathrm{x}$ & $\mathrm{x}$ & $\mathrm{x}$ & $\mathrm{x}$ & $\mathrm{x}$ & & & & & & \\
\hline & \multirow{5}{*}{ Beetle } & Fusarium sp. & & & $\mathrm{x}$ & & $\mathrm{x}$ & & & & & & $2 / 5$ \\
\hline & & AF-8 & $\mathrm{x}$ & $\mathrm{x}$ & & & & & & & & & $2 / 5$ \\
\hline & & G. euwallaceae & $\mathrm{x}$ & & & & $\mathrm{x}$ & & & & & & $2 / 5$ \\
\hline & & Acremonium sp. & & & & & $\mathrm{x}$ & & & & & & $1 / 5$ \\
\hline & & Elaphocordyceps sp. & & & & & $\mathrm{x}$ & & & & & & $1 / 5$ \\
\hline \multirow{4}{*}{$\begin{array}{c}\text { Location } 5 \\
25^{\circ} 35^{\prime} 50^{\prime \prime} \mathrm{N} \\
80^{\circ} 30^{\prime} 16^{\prime \prime} \mathrm{W}\end{array}$} & $\begin{array}{l}\text { Plant } \\
\text { tissue }\end{array}$ & Fusarium sp. & $\mathrm{x}$ & $\mathrm{x}$ & $\mathrm{x}$ & $\mathrm{x}$ & $\mathrm{x}$ & & & & & & $5 / 5$ \\
\hline & \multirow{3}{*}{ Beetle } & Fusarium sp. & $\mathrm{x}$ & $\mathrm{x}$ & $\mathrm{x}$ & $\mathrm{x}$ & $\mathrm{x}$ & & & & & & $5 / 5$ \\
\hline & & G. euwallaceae & $\mathrm{x}$ & $\mathrm{x}$ & $\mathrm{x}$ & $\mathrm{x}$ & $\mathrm{x}$ & & & & & & $5 / 5$ \\
\hline & & A. morum & & & & & $\mathrm{x}$ & & & & & & $1 / 5$ \\
\hline \multirow{7}{*}{$\begin{array}{c}\text { Location } 6 \\
25^{\circ} 31^{\prime} 31^{\prime \prime} \mathrm{N} \\
80^{\circ} 30^{\prime} 16^{\prime \prime} \mathrm{W}\end{array}$} & \multirow{3}{*}{$\begin{array}{l}\text { Plant } \\
\text { tissue }\end{array}$} & Fusarium sp. & $\mathrm{x}$ & $\mathrm{x}$ & $\mathrm{x}$ & & & & & & & & $3 / 5$ \\
\hline & & AF-8 & & & & $\mathrm{x}$ & & & & & & & $1 / 5$ \\
\hline & & AF-6 & & & & & $\mathrm{x}$ & & & & & & $1 / 5$ \\
\hline & \multirow{4}{*}{ Beetle } & Fusarium sp. & $\mathrm{x}$ & & $\mathrm{x}$ & $\mathrm{x}$ & $\mathrm{x}$ & $\mathrm{x}$ & $\mathrm{x}$ & $\mathrm{x}$ & $\mathrm{x}$ & $\mathrm{x}$ & $9 / 10$ \\
\hline & & G. euwallaceae & $\mathrm{x}$ & & & & $\mathrm{x}$ & & $\mathrm{x}$ & $\mathrm{x}$ & $\mathrm{x}$ & $\mathrm{x}$ & $5 / 10$ \\
\hline & & Acremonium sp. & & & & & & & & & & $\mathrm{x}$ & $1 / 10$ \\
\hline & & Elaphocordyceps sp. & & & $\mathrm{x}$ & & & & & & & & $1 / 10$ \\
\hline
\end{tabular}




\section{Discussion}

All beetles sampled from 33 locations within the avocado growing region matched E. nr. fornicatus sp. \#2, which suggested a single introduction or multiple introductions of the same species into Florida. This species has now invaded the entire commercial avocado production area in Miami-Dade County. Little is known about the host range of E. nr. fornicatus sp. \#2 in Florida. It was first reported in the state in 2002 attacking Royal Poinciana (Delonix regia (Boj. ex Hook.) Raf.; Fabales: Fabaceae), and 10 years later, was found attacking avocado trees [7]. In subsequent years, the beetle was detected in seven avocado orchards [10] and associated with dead branches of a mango tree at the University of Florida Tropical Research and Education Center at Homestead, Florida [24]. The widespread distribution of the beetle in the avocado growing region, and the finding of $E$. nr. fornicatus infestations in avocado at Fort Myers (Lee County, FL, USA) and in swampbay (Persea palustris (Raf.) Sarg.) trees at Lake Placid (Highlands County, FL, USA) approximately $250 \mathrm{~km}$ from the commercial production region, suggests that other host plants could be facilitating the spread of this beetle in Florida. In addition, this beetle can potentially spread through movement of infested nursery stock [25]. Species within the E. fornicatus complex have been reported to be highly polyphagous, attacking more than 300 host species in 58 plant families; including avocado in California and Israel $[3,4,26,27]$. There are three distinct races of avocados: Mexican, Guatemalan and West Indian. Some important commercial cultivars are hybrids of the various races. All previous reports of damage on avocado by E. nr. fornicatus species were on Guatemalan, Mexican, or Guatemalan-Mexican avocado hybrids, which are grown commercially in California and Israel. Here we report infestations on West Indian and West Indian-Guatemalan avocado hybrids grown in Florida. Affected varieties in the orchard with the detected outbreak include: "Donnie", "Beta", "Dupuis" "Monroe" and "Buck 3". Donnie, the most abundant cultivar in the orchard, was more affected than the other cultivars in the grove. More studies are needed to determine avocado cultivar preferences by E. nr. fornicatus in Florida. The host plant range of E. nr. fornicatus in Florida warrants further attention.

Earlier work with E. nr. fornicatus was initiated when this beetle was first detected attacking avocado in Florida [7]. Kasson et al. [8] and O'Donnell et al. [2] reported that E. nr. fornicatus sp. \#2 was associated with AF-8 and AF-6. These studies were conducted with a limited number of samples from the original detection site, and prior to populations reaching damaging levels. In this 2016 study, with a broader sample universe, an unknown Fusarium sp. was the most abundant and frequently found fungus associated with E. nr. fornicatus. Current identification of AF species is based in on EF- $1 \alpha$, ITS, RBP1 and RBP2 sequences. EF- $1 \alpha$ is considered highly informative and instrumental to resolve all known species within the AFC [2]. Fusarium sp. isolates found in this study displayed 99\% of identity with EF- $1 \alpha$ and RBP2 primer set 7cf/11 of Fusarium ambrosium, but RPB2 primer set $5 \mathrm{f} 2 / 7 \mathrm{cr}$ sequence showed similar percentage of identity with AF-4. Similarly, Kasson et al. [8] reported the existence of putative interspecific $F$. ambrosium hybrids with EF- $1 \alpha$, rDNA and RBP1 sequences identical to F. ambrosium but RBP2 sequence matching AF-4. EF-1 $\alpha$ and partial RBP2 sequences support the dominant Fusarium sp. in this study as a member of AFC closely related to F. ambrosium. Further phylogenetic analysis and the identification of additional DNA sequence markers may be required for the recognition and diagnosis of this Fusarium sp. Overall the available evidence suggests that E. nr. fornicatus sp. \#2 can be associated with at least three species of the AFC and that beetle-fusaria associations may not be obligate. Other studies have shown similar plasticity in ambrosia beetle-fungi associations [1]. In previous detections of E. nr. fornicatus associated with AF-8 and AF-6, the latter were not causing conspicuous damage to avocados. Here we document populations of this beetle associated with an unknown Fusarium sp. causing significant damage in two south Florida avocado orchards. This Fusarium sp. was prevalent in xylem lesions surrounding the beetle galleries unlike AF-8 and AF-6, which were seldom found associated with the lesions. Other fungi isolated from beetles (Graphium euwallacea and Acremonium spp.) were not recovered from lesions, and this suggests that they may grow confined mostly in beetle galleries and play a role in the beetle's nutrition. The available evidence suggests that this unknown Fusarium sp. is the main fungus contributing to the damage of 
avocado in south Florida. The role of Fusarium sp. in the recent outbreak and its pathogenicity to avocados also warrants further research.

Graphium euwallacea was the second most frequent and abundant fungal associate of E. nr fornicatus in Florida. This fungus was reported in association with E. nr. fornicatus sp. \#1 in Israel [27] and California [6]. Other Graphium sp. have been reported in association with Euwallacea validus (Eichhoff 1875) by O'Donnell et al. [2], who suggested an ancestral association between Graphium fungi and Euwallacea species. Our findings support this hypothesis but differ from the reports of pathogenicity of G. euwallacea to avocado [6]. In our survey, G. euwallacea was not recovered from any of the wood lesions surrounding the beetle galleries, and this suggests that the growth of this fungus is limited to the beetle galleries. According to Freeman et al. [27] G. euwallacea is the predominant symbiont in the initial stages of gallery formation and the main food source (i.e., dominant fungus) for larvae during their development. Graphium euwallacea is consumed during maturation of adult beetles when F. euwallacea becomes more readily available. Controlled experiments are needed to understand the dynamics and nutritional attributes of the fungal species throughout the life cycle of E. nr. fornicatus in Florida.

Three bacterial species were recovered from adult female E. nr. fornicatus in Florida. The bacteria most frequently observed were identified as Sphigomonas spp. (Sphigomonodales: Sphigomonodaceae), gram-negative bacteria in the $\alpha-4$ subclass of the Protobacteria, known for their biodegradative capabilities, comprising cellulose aromatic compounds and lignin degradation [28]. They have been found associated with plant roots, and in some cases show antagonism against pathogenic fungi [29]. This characteristic could be associated with their ability to produce degradative enzymes such as chitinases as was reported for these bacterial species by Zhu et al. [30]. Sphigomonas also have been found as endophytes of two tree species—cottonwood (Populus sp.; Malpighiales: Saliaceae) and willow (Salix sp.; Malpighiales: Saliaceae)—showing nitrogen fixing capabilities in a symbiotic relationship that helps the plant survive under nutrient-poor conditions [31]. The second most common bacterial associate was identified as Chryseobacterium sp. (Flavobacteriales: Flavobacteriaceae), a gram-negative, non-motile, non-spore-forming, filamentous bacterium, and member of the heterogeneous group Cytophaga-Flavobacterium-Bacteroides [32]. Chryseobacterium sp. isolates from insect gut microbiota have been shown to produce wood degrading enzymes such as pectinase in longhorned beetles (Cerambycidae) [33], and cellulose degrading enzymes, cellobiohydrolase and $\beta$-glucosidase in termites [34]. The third bacterium identified belongs to the genus Ochrobactrum (Rhizobiales: Brucellaceae), in the $\alpha-2$ subclass of the proteobacteria, a gram-negative non-spore forming, strictly aerobic bacterium [35]. Octobractum has been found in termite guts forming part of their microbiota that functions in hemicellulose degradation [36]. In general, studies have shown that insect-gut associated bacteria may play a role in insect nutrition, most likely by providing nitrogen and micronutrients, by detoxifying secondary plant compounds through enzymatic degradation and by "keeping clean" the ambrosia fungal culture through antagonistic effects against foreign fungal contaminants [37,38].

In addition, three yeast species were recovered from E. nr. fornicatus in Florida, including Lipomyces oligophage (Van der Walt \& Arx) Kurtzman, Albertyn \& Basehoar-Powers (Saccharomycetales: Lipomycetaceae), Candida germanica Kurtzman, Robnett \& Yarrow (Saccharomycetales), and Hannaella sp. (Ascomycota: Schizosaccharomycotina: Tremelales). Zygozyma oligophaga (Saccharomycetales: Lipomycetaceae), the type species of the genus Zygozyma, has only been isolated from two frass samples: one from an unidentified bark beetle in a Ficus trichpoda Naker (Rosales: Moraceae), and one from the platypoid ambrosia beetle, Crossotarsus externedentatus Scheidl, infesting Macaranga capensis Benth (Malpighiales: Euphorbiaceae), both in South Africa [39,40]. The literature for this group only covers the basic description of the genera but provides no information regarding their functions as insect-associates. Candida germanica was isolated from the atmosphere over Germany [41] and no additional reports are available. Other Candida species have been isolated from the galleries, frass, and guts of different beetle species [42], and in many cases their extracellular enzymatic production profile links them with wood degradation [43]. The genus Hannaella comprises few species that are 
mainly phyllosphere-inhabiting yeasts [44]. Hannaella spp. have been isolated from the integuments of leafcutter ant males and fungus gardens of the leafcutter ants, where they are believed to function in plant material degradation, making nutrients available for the mutualistic fungus and the ants, as evidenced by the production of enzymes such as pectinases, polygalacturonases, lipases ligninases, and xylaneses. In addition, Hannaella spp. consumed galacturonic acid resulting from the degradation of the plant pectins, otherwise, toxic to the fungal symbiont [45]. Similar to the bacterial symbionts, yeast may have a role in nutrient availability and detoxification of deleterious compounds.

\section{Conclusions}

The recent outbreak of E. nr. fornicatus beetles in two avocado orchards in Florida causing extensive branch dieback warrants further attention by tropical fruit growers, entomologists, and plant pathologists. More research is needed to determine which factors trigger attacks by this beetle. The role of Fusarium sp. in the recent outbreak and its pathogenicity to avocados also warrants further research. While integrated pest management programs are developed for this pest beetle, avocado growers should periodically survey for trees showing branch dieback and signs of beetle attack at junctions of small and mid-size shaded branches showing the presence white "sugar volcanoes". Infested branches should be removed and destroyed (chipped, burned or buried) to prevent further spread of these beetles. During our south Florida survey a large number of beetles were captured in locations with no apparent damage to the avocado trees suggesting that E. nr. fornicatus are associated with other host(s) outside the groves or with dead trees or branches inside the grove. Notably, most of the surveyed locations have had laurel wilt infections in the recent years, which could have influenced the abundance of E. nr. fornicatus by increasing the availability of dying and dead trees. More research is needed to determine the host range of E. nr. fornicatus and the potential threat that this beetle and its fungal associates pose to the avocado industry in south Florida.

Acknowledgments: We thank Carlos de la Torre for providing access to the avocado orchard with the initial E. nr. fornicatus outbreak and the Florida Avocado Administrative Committee for facilitating access to 32 additional orchards. We thank John Molongoski for assistance with molecular diagnostic methods and Waldemar Klassen for suggestions to improve the manuscript. We also thank ChemTica USA (Durant, OK, USA) for providing the lures containing quercivorol. Mention of trade names or commercial products in this article is solely for the purpose of providing specific information and does not imply recommendation or endorsement by the U.S. Department of Agriculture. USDA is an equal opportunity provider and employer. This research was partially funded by a USDA-APHIS Farm Bill grant to M. F. Cooperband and D. Carrillo (USDA 14-8130-0364-CA).

Author Contributions: Daniel Carrillo, Luisa F. Cruz, and Paul E. Kendra conceived and designed the surveys; Luisa F. Cruz, Teresa I. Narvaez, Wayne S. Montgomery and Armando Monterroso performed the surveys; Daniel Carrillo, Luisa F. Cruz and Charlotte De Grave analyzed the data; Miriam F. Cooperband contributed reagents/materials/analysis tools; Daniel Carrillo and Luisa F. Cruz wrote the paper.

Conflicts of Interest: The authors declare no conflict of interest.

\section{References}

1. Carrillo, D.; Duncan, R.E.; Ploetz, J.N.; Campbell, A.F.; Ploetz, R.C.; Peña, J.E. Lateral transfer of a phytopathogenic symbiont among native and exotic ambrosia beetles. Plant Pathol. 2014, 63, 54-62. [CrossRef]

2. O’Donnell, K.; Sink, S.; Ran, L.H.R.; Hulcr, J.; Kasson, M.T.; Ploetz, C.R.; Konkol, J.L.; Ploetz, J.N.; Carrillo, D.; Campbell, A.; et al. Discordant phylogenies suggest repeated host shifts in the Fusarium-Euwallacea ambrosia beetle mutualism. Fungal Genet. Biol. 2015, 82, 277-290. [CrossRef] [PubMed]

3. Eskalen, A. Host range of Fusarium dieback and its ambrosia beetle (Coleoptera: Scolytinae) vector in Southern California. Plant Dis. 2013, 97, 938-951. [CrossRef]

4. Mendel, Z.; Protasov, A.; Sharon, M.; Zveibil, A.; Yehuda, S.B.; O’Donnell, K.; Rabaglia, R.; Wysoki, M.; Freeman, S. An Asian ambrosia beetle Euwallacea fornicatus and its novel symbiotic fungus Fusarium sp. pose a serious threat to the Israeli avocado industry. Phytoparasitica 2012, 40, 235-238. [CrossRef]

5. Freeman, S.; Sharon, M.; Maymon, M.; Mendel, Z.; Protasov, A.; Aoki, T.; Eskalen, A.; O’Donnell, K. Fusarium euwallaceae sp. nov.-A symbiotic fungus of Euwallacea sp., an invasive ambrosia beetle in Israel and California. Mycologia 2013, 105, 1595-1606. [CrossRef] [PubMed] 
6. Lynch, S.C.; Twizeyimana, M.; Mayorquin, J.S.; Wang, D.H.; Na, F.; Kayim, M.; Kasson, M.T.; Thu, P.Q.; Bateman, C.; Rugman-Jones, P.; et al. Identification, pathogenicity and abundance of Paracremonium pembeum sp. nov. and Graphium euwallaceae sp. nov. two newly discovered mycangial associates of the polyphagous shot hole borer (Euwallacea sp.) in California. Mycologia 2016, 108, 313-329. [CrossRef] [PubMed]

7. Carrillo, D.; Duncan, R.; Peña, J.E. Ambrosia beetles (Curculionidae: Scolytinae) that breed in avocado wood in Florida. Fla. Entomol. 2012, 95, 573-579. [CrossRef]

8. Kasson, M.T.; O’Donnell, K.; Rooney, A.P.; Sink, S.; Ploetz, R.C.; Ploetz, J.N.; Konkol, J.L.; Carrillo, D.; Freeman, S.; Mendel, Z.; et al. Aninordinate fondness for Fusarium: Phylogenetic diversity of fusaria cultivated by ambrosia beetles in the genus Euwallacea on avocado and other plant hosts. Fungal Genet. Biol. 2013, 56, 147-157. [CrossRef] [PubMed]

9. Cooperband, M.F.; Stouthamer, R.; Carrillo, D.; Eskalen, A.; Thibault, T.; Cossé, A.A.; Castrillo, L.A.; Vandenberg, J.D.; Rugman-Jones, P.F. Biology of two members of the Euwallacea fornicatus species complex (Coleoptera: Curculionidae: Scolytinae), recently invasive in the USA, reared on an ambrosia beetle artificial diet. Agric. For. Entomol. 2016, 18, 223-237. [CrossRef]

10. Carrillo, D.; Narvaez, T.; Cossé, A.A.; Stouthamer, R.; Cooperband, M.F. Attraction of Euwallacea nr. fornicatus (Coleoptera: Curculionidae: Scolytinae) to lures containing quercivorol. Fla. Entomol. 2015, 98, 780-782.

11. Carrillo, D.; IFAS-Tropical Research and Education Center, University of Florida, Homestead, FL, USA. Personal observation, 2015.

12. De La Torre, C.; Tree Injection Systems LLC. Homestead, FL, USA. Personal Communication, 2016.

13. United States Department of Agriculture, National Agricultural Statistics Service. Census of Agriculture 2012. Available online: https:/ / quickstats.nass.usda.gov/results/2126FF9A-4DBC-3F8E-9BB8-CA1976617919 (accessed on 11 October 2016).

14. United States Department of Agriculture, National Agricultural Statistics Service. Census of Agriculture 2012. Available online: https:/ / quickstats.nass.usda.gov/results /AA8D651A-9946-3384-8098-D0D9FDEAC0FC (accessed on 11 October 2016).

15. Kendra, P.E.; Narvaez, T.I.; Montgomery, W.S.; Carrillo, D. Ambrosia beetle communities in forest and agricultural ecosystems with laurel wilt disease. In Proceedings of the 53rd Annual Meeting of the Entomological Society of America, Minneapolis, MN, USA, 15-18 November 2015.

16. Doyle, J.; Doyle, J.L. Genomic plant DNA preparation from fresh tissue-CTAB method. Phytochem. Bull. 1987, 19, 11-15.

17. Folmer, O.; Black, M.; Hoeh, W.; Lutz, R.; Vrijenhoek, R. DNA primers for amplification of mitochondrial cytochrome C oxidase subunit I from diverse metazoan invertebrates. Mol. Mar. Biol. Biotechnol. 1994, 3, 294-299. [PubMed]

18. Dole, S.A.; Jordal, B.H.; Cognato, A.I. Polyphyly of Xylosandrus Reitter inferred from nuclear and mitochondrial genes (Coleoptera: Curculionidae: Scolytinae). Mol. Phylogenetics Evol. 2010, 54, 773-782. [CrossRef] [PubMed]

19. O’Donnell, K.; Kistler, H.C.; Cigelnik, E.; Ploetz, R.C. Multiple evolutionary origins of the fungus causing Panama disease of banana: Concordant evidence from nuclear and mitochondrial gene genealogies. Proc. Natl. Acad. Sci. USA 1998, 95, 2044-2049. [CrossRef] [PubMed]

20. Liu, Y.J.; Whelen, S.; Hall, B.D. Phylogenetic relationships among ascomycetes: Evidence from an RNA polymerase II subunit. Mol. Biol. Evol. 1999, 16, 1799-1808. [CrossRef] [PubMed]

21. Vilgalys, R.; Hester, M. Rapid genetic identification and mapping of enzymatically amplified ribosomal DNA from several Cryptococcus species. J. Bacteriol. 1990, 172, 4239-4246.

22. White, T.J.; Bruns, T.; Lee, S.; Taylor, J. Amplification and direct sequencing of fungal ribosomal RNA genes for phylogenies. In PCR Protocols, a Guide to Methods and Applications; Academic Press: Cambridge, MA, USA, 1990; pp. 315-322.

23. Marchesi, J.R.; Sato, T.; Weightman, A.J.; Martin, T.A.; Fry, J.C.; Hiom, S.J.; Wade, W.G. Design and evaluation of useful bacterium-specific PCR primers that amplify genes coding for bacterial 16S rRNA. Appl. Environ. Microbiol. 1998, 64, 795-799. [PubMed]

24. Carrillo, D.; IFAS-Tropical Research and Education Center, University of Florida, Homestead, FL, USA. Personal observation, 2016.

25. Cooperband, M.C.; Otis Laboratory, Plant Protection and Quarantine's Science and Technology, Animal and Plant Health Inspection Service, United States Department of Agriculture, Buzzards Bay, MA, USA. Personal communication, 2013. 
26. Danthanarayana, W. The distribution and host-range of the shot-hole borer (Xyleborus fornicatus Eichh.) of tea. Tea Q. 1968, 39, 61-69.

27. Freeman, S.; Sharon, M.; Dori-Bachash, M.; Maymon, M.; Belausov, E.; Maoz, Y.; Margalit, O.; Protasov, A.; Mendel, Z. Symbiotic association of three fungal species throughout the life cycle of the ambrosia beetle Euwallacea nr. fornicatus. Symbiosis 2016, 68, 115-128. [CrossRef]

28. Bugg, T.D.; Ahmad, M.; Hardiman, E.M.; Singh, R. The emerging role for bacteria in lignin degradation and bio-product formation. Curr. Opin. Biotechnol. 2011, 22, 394-400. [CrossRef] [PubMed]

29. White, D.C.; Sutton, S.D.; Ringelberg, D.B. The genus Sphingomonas: Physiology and ecology. Curr. Opin. Biotechnol. 1996, 7, 301-306. [CrossRef]

30. Zhu, X.; Zhou, Y.; Fenf, J. Analysis of both chitinase and chitosanase produced by Sphingomonas sp. CJ-5. J. Zhejiang Univ. Sci. 2007, 8, 831-838. [CrossRef] [PubMed]

31. Doty, S.L.; Oakley, B.; Xin, G.; Kang, J.W.; Singleton, G.; Khan, Z.; Vajzovic, A.; Staley, J.T. Diazotrophic endophytes of native black cottonwood and willow. Symbiosis 2009, 47, 23-33. [CrossRef]

32. Vandamme, P.; Bernardet, J.F.; Segers, P.; Kersters, K.; Holmes, B. New Perspectives in the Classification of the Flavobacteria: Description of Chryseobacterium gen. nov., Bergeyella gen. nov., and Empedobacter nom. rev. Int. J. Syst. Evol. Microbiol. 1994, 44, 827-831. [CrossRef]

33. Park, D.; Oh, H.; Jeong, W.; Kim, H.; Park, H.; Bae, K.S. A culture-based study of the bacterial communities within the guts of nine longicorn beetle species and their exo-enzyme producing properties for degrading xylan and pectin. J. Microbiol. Seoul 2007, 45, 394-401.

34. Cho, M.J.; Kim, Y.H.; Shin, K.; Kim, Y.K.; Kim, Y.S.; Kim, T.J. Symbiotic adaptation of bacteria in the gut of Reticulitermes speratus: Low endo- $\beta-1,4$-glucanase activity. Biochem. Biophys. Res. Commun. 2010, 395, 432-435. [CrossRef] [PubMed]

35. Swings, J.; Lambert, B.; Kersters, K.; Holmes, B. The genera Phyllobacterium and Ochrobactrum. In The Prokaryotes, a handbook on the biology of bacteria, ecophysiology, isolation, identification and applications, 3th ed.; Falkow, S., Rosenberg, E., Schleifer, K.H., Stackebrandt, E., Eds.; Springer Science \& Business Media: New York, NY, USA, 2006; Volume 5, pp. 747-750.

36. Schäfer, A.; Konra, R.; Kuhnigk, T.; Kämpfer, P.; Hertel, H.; König, H. Hemicellulose-degrading bacteria and yeasts from the termite gut. J. Appl. Bacteriol. 1996, 80, 471-478. [CrossRef] [PubMed]

37. Calderón-Cortés, N.; Quesada, M.; Watanabe, H.; Cano-Camacho, H.; Oyama, K. Endogenous plant cell wall digestion: A key mechanism in insect evolution. Annu. Rev. Ecol. Evol. Syst. 2012, 43, 45-71. [CrossRef]

38. Oliver, K.M.; Degnen, P.H.; Burke, G.R.; Moran, N.A. Facultative symbionts in aphids and the horizontal transfer of ecologically important traits. Annu. Rev. Entomol. 2010, 55, 247-266. [CrossRef] [PubMed]

39. Van der Walt, J.P.; Von Arx, J.A.; Ferreira, N.P.; Richards, P.D.G. Zygozyma, a new genus of the Lipornycetaceae. Syst. Appl. Microbiol. 1987, 9, 115-120. [CrossRef]

40. Van der Walt, J.P.; Wingfield, M.J.; Yamada, Y. Zygozyma smithiae sp. n. (Lipomycetaceae), a new ambrosia yeast from Southern Africa. Antonie Van Leeuwenhoek 1990, 58, 95-98. [CrossRef] [PubMed]

41. Kurtzman, C.P.; Robnett, C.J.; Yarrow, D. Two new anamorphic yeasts: Candida germanica and Candida neerlandica. Antonie Van Leeuwenhoek 2001, 80, 77-83. [CrossRef] [PubMed]

42. Suh, S.O.; Nguyen, N.H.; Blackwell, M. Yeasts isolated from plant-associated beetles and other insects: Seven novel Candida species near Candida albicans. FEMS Yeast Res. 2008, 8, 88-102. [CrossRef] [PubMed]

43. Yun, Y.H.; Suh, D.Y.; Yoo, H.D.; Oh, M.H.; Kim, S.H. Yeast Associated with the Ambrosia Beetle, Platypus koryoensis, the Pest of Oak Trees in Korea. Mycobiology 2015, 43, 458-466. [CrossRef] [PubMed]

44. Landell, M.F.; Brandão, L.R.; Barbosa, A.C.; Ramos, J.P.; Safar, S.V.; Gomes, F.C.; Sousa, F.M.; Morais, P.B.; Broetto, L.; Leoncini, O.; et al. Hannaella pagnoccae sp. nov., a tremellaceous yeast species isolated from plants and soil. Int. J. Syst. Evol. Microbiol. 2014, 64, 1970-1977. [CrossRef] [PubMed]

45. Arcuri, S.L.; Pagnocca, F.C.; da Paixão Melo, W.G.; Nagamoto, N.S.; Komura, D.L.; Rodrigues, A. Yeasts found on an ephemeral reproductive caste of the leaf-cutting ant Atta sexdens rubropilosa. Antonie Van Leeuwenhoek 2014, 106, 475-487. [CrossRef] [PubMed]

(C) 2016 by the authors; licensee MDPI, Basel, Switzerland. This article is an open access article distributed under the terms and conditions of the Creative Commons Attribution (CC-BY) license (http://creativecommons.org/licenses/by/4.0/). 